\title{
Herbicidal Activities and Selectivity of a New Rice Herbicide DPX-F5384
}

\author{
Shunji Takeda, Takeshi Yuyama, Robert C. Ackerson*, Russell C. Weigel**, \\ Richard F. Sauers*, Warnell Neal*, David G. Gibian** and Paul K. Tseng* \\ Agricultural Science Laboratory, Agrichemicals Division, Du Pont Japan Ltd. \\ Kashiwada 856, Ushiku, Ibaraki 300-12, Japan
}

\section{Introduction}

DPX-F5384 is one of the sulfonylurea herbicides discovered and developed by E. I. du Pont de Nemours and Co., Inc. Chlorsulfuron and sulfometuron methyl have been commercialized, while metsulfuron methyl and DPX-F6025 are at the final step of development for registration.

As a selective herbicide for transplanted and direct-seeded rice, DPX-F5384 was selected from among many sulfonylurea compounds as shown the previous paper. ${ }^{5)}$ The compound is active at a rate as low as $20 \sim$ $50 \mathrm{~g} \mathrm{a}$ i. / ha and has excellent activity on most annual and perennial weeds which infest rice paddies. ${ }^{4,5)}$

In this report, we elucidate some of the salient biological and physical properties of DPX-F5384, such as herbicidal activity, safety for rice plant, selectivity and mobility in paddy soil.

\section{Materials and Methods}

Chemistry of the compound and physical and chemical properties are shown in Table 1.

\section{Herbicidal Activity and Crop Safety}

1) Wagner pot test

Pre-emergence herbicidal activities and crop safety under paddy conditions were deter- mined through greenhouse pot tests.

The test was conducted using $200 \mathrm{~cm}^{2}$ Wagner pots filled with paddy soil (alluvium clay loam, O. M. $=5.9 \%$ ). After adding fertilizer (N. P. K, 15-15-15, $1.5 \mathrm{~g} /$ pot), the weed seeds and tubers listed in Table 2 were planted in the top soil and water was intr-

Table 1. Physicochemical properties of DPX-F5384 o Chemical structure:

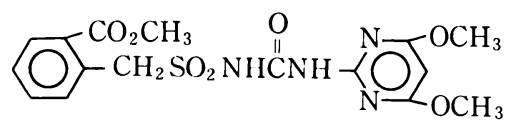

O Molecular weight: $\quad 410.40$

○ Physical state:

Melting point :

White to pale yellow, solid

- Vapor pressure : $185-188^{\circ} \mathrm{C}$

$1.3 \times 10^{-5} \mathrm{~mm} \mathrm{Hg}$ at $20^{\circ} \mathrm{C}$

- Solubility in organic solvent $\left(20^{\circ} \mathrm{C}\right)$ :

$\begin{array}{lr}\text { Methylene chloride } & 11,720 \mathrm{ppm} \\ \text { Acetonitrile } & 5,380 \\ \text { Ethyl acetate } & 1,660 \\ \text { Acetone } & 1,380\end{array}$

Solubility in buffered water $\left(25^{\circ} \mathrm{C}\right)$ :

\begin{tabular}{lrrr} 
& ppm & final pH* \\
\cline { 3 - 4 } & \multicolumn{1}{c}{$\begin{array}{l}\text { pH5 (0.05M Sodium Phosphate Buffer) } \\
\text { pH6 (0.05M Sodium Phosphate Buffer) }\end{array}$} & 12.0 & 5.8 \\
pH7 (0.05M Sodium Phosphate Buffer) & 120.0 & 6.9 \\
pH8 (0.05M Sodium Phosphate Buffer) & 1200.0 & 7.8 \\
*Final pH measured after solvent was saturated \\
with DPX-F5384
\end{tabular}

* Agricultural Chemicals Department, E. I. du Pont de Nemours \& Co. Inc., Wilmington, Delaware 19898, U.S. A.

** Department of Botany, University of Tennessee, Knoxville, Tennessee 37966, U.S. A. 
oduced to a depth of $1 \mathrm{~cm}$ above the soil. Rice seedlings (cv. "Nihonbare") at the 2.2 leafstage were transplanted at the rate of 4 seedlings ( 2 stands)/pot and water to a depth of $3 \mathrm{~cm}$ was added.

After transplanting of rice seedligs, the chemicals (granule formulation) were applied as pre-emergence treatments to the weeds. Every treatment including an untreated check, was replicated three times. After that, the pots were kept in the greenhouse for 30 days, and then weed control and crop injury were visually judged by a zero to 10 rating system: zero $=$ no effect, $\geqq 3$ =unacceptable, and 10 $=$ complete kill. The above-the-soil part of the rice plants was then cut off and put in an electric dryer maintained at $70^{\circ} \mathrm{C}$ for 48 hours to measure the dry weight.

2) Concrete pot test

Using concrete pots $50 \times 50 \mathrm{~cm}$ in size, the test was conducted in a similar manner as the wagner pot test under outdoor conditions replicated two times. Seeds of weeds listed in Table 3 were incorporated into the paddy soil. After introducing the water, rice seedlings of the 2.2 leafstage (cv. "Nihonbare") were transplanted at the rate of 2 plants/stand, with 8 stands/pot. After watering to a $3 \mathrm{~cm}$ depth, the chemicals (granules) were applied to the water. Starting 24 hours after application, water was leaked at the rate of $2 \mathrm{~cm} /$ day for 2 days. Water was maintained at a depth of $3 \mathrm{~cm}$ through the test periods. Herbicidal activity and crop safety were evaluated 30 days after application.

\section{3) Field test}

The test in the paddy field (diluvium clay loam, O. M. $=15.7 \%$ ) was carried out in Ushiku, Ibaraki Prefecture as follows: Plots for weed control and crop safety evaluation were $1 \mathrm{~m}^{2}$ and $2 \mathrm{~m}^{2}$, respectively, and were replicated two times. Rice seedlings of the 2.5 leafstage were transplanted by hand on May 14, 1981 and the chemicals (granules) were applied 5 days and 12 days after trans- planting. Herbicidal activity and crop safety were rated visually 30 days after application. Number of stems, plant height and dry weight of the above-the-soil part were then measured.

\section{Sensitivity Difference between Gramineous} and Broadleaf Plants

Upland soil (diluvium clay loam, O. M.= $6.9 \%$ ) was evenly laid $2 \mathrm{~cm}$ thick into shallow containers. Water solutions of DPX-F5384 at the various rates shown in Table 5 were uniformly sprayed on the soil surface, and the soil was sufficiently mixed. Each treated soil was transferred into a plastic container. Seeds of rice (Oryza sativa, cv. Nihonbare), wheat (Triticum aestivum, cv. Norin-61), Chinese cabbage (Brassica pekinensis, cv. Santosai) and spinach (Spinacia aleracea, cv. Symhony) were sown on the soil surface. Also, rice as well as other upland crops was grown under upland conditions. Rating was made 14 days after sowing.

\section{Mobility in paddy soil}

The test was conducted using plastic cylinders each consisting of ten connected rings, each ring $10 \mathrm{~cm}$ in diameter and $1 \mathrm{~cm}$ in depth. The middle 5 rings and bottom 2 rings were filled with sieved paddy soil (alluvium loam) and sand, respectively. These cylinders - were put in water containers, then water was added until the level reached the surface of the soil at the top of the cylinders. After puddling, water was introduced to a depth of $3 \mathrm{~cm}$ above the soil. DPX-F5384 granules at the rate of 75 and $150 \mathrm{~g}$ a. i./ha were applied to the water at the top of the cylinders. After 24 hours, water was drawn down at the rate of $1 \mathrm{~cm} / 4$ hours until fully drained. Soil held in each ring was transferred into a plastic containers. Water was added to simulate paddy conditions. Then 15 seeds of Echinochloa oryzicola and Scirpus juncoides were sown on the soil. Fresh shoots of both weeds were weighed 14 days after the seeding. 
Table 2. Herbicidal activity and crop injury of DPX-F5384 (Greenhouse Pot Test)

\begin{tabular}{|c|c|c|c|c|c|c|c|c|c|c|}
\hline \multirow{2}{*}{ Chemicals } & \multirow{2}{*}{$\begin{array}{c}\text { Rate } \\
\text { g a. i. /ha }\end{array}$} & \multirow{2}{*}{$\begin{array}{l}\text { Timing } \\
\text { DAT }\end{array}$} & \multirow{2}{*}{$\frac{\text { Crop }}{\text { V. C. }}$} & \multirow{2}{*}{$\frac{\text { Injury }}{\text { D. W. }}$} & \multicolumn{6}{|c|}{ Weed Control } \\
\hline & & & & & Eo & $\mathrm{Mv}$ & $\mathrm{Bl}$ & $\mathrm{Sj}$ & $\mathrm{Sp}$ & $\mathrm{Cs}$ \\
\hline \multirow[t]{3}{*}{ DPX-F5384 } & 25 & 3 & 0 & 105 & 0 & 10 & 10 & 8 & 9 & 10 \\
\hline & 50 & & 0 & 102 & 5 & 10 & 10 & 9.5 & 9.5 & 10 \\
\hline & 100 & & 2 & 90 & 7 & 10 & 10 & 10 & 10 & 10 \\
\hline
\end{tabular}

DAT: after transplanting, Timing: Pre-emergence to weeds V.C.: Visual Count ( $0 \sim 10$ rating scale), D. W. : Dry Weight of Shoot (\% of untreated check)

Eo : Echinochloa oryzicola, Mv : Monochoria vaginalis, Bl : Annual Broadleaf weeds,

$\mathrm{Sj}$ : Scirpus juncoides, Sp : Sagittaria pygmaea, Cs : Cyperus Serotinus

Table 3. Herbicidal activity and crop injury of DPX-F5384 (Outdoors Pot Test)

\begin{tabular}{|c|c|c|c|c|c|c|c|c|c|c|c|c|c|}
\hline \multirow{3}{*}{ Chemicals } & \multirow{3}{*}{$\begin{array}{l}\text { Rate } \\
\text { g a. i. } / \text { ha }\end{array}$} & \multicolumn{12}{|c|}{ Herbicidal Activity } \\
\hline & & \multicolumn{6}{|c|}{ Pre-emergence } & \multicolumn{6}{|c|}{ Post-emergence } \\
\hline & & Rice & Eo & $\mathrm{Bl}$ & $\mathrm{Sj}$ & $\mathrm{Sp}$ & $\mathrm{Cs}$ & Rice & Eo & $\mathrm{Bl}$ & $\mathrm{Sj}$ & $\mathrm{Sp}$ & $\overline{\mathrm{Cs}}$ \\
\hline \multirow[t]{3}{*}{ DPX-F5384 } & 50 & 0 & 4 & 10 & 9.5 & 9.5 & 9.5 & 0 & 3 & 10 & 9 & 9 & 9 \\
\hline & 100 & 1 & 7 & 10 & 10 & 10 & 10 & 0 & 5 & 10 & 9.5 & 9.5 & 9.5 \\
\hline & 200 & 3 & 9 & 10 & 10 & 10 & 10 & 1 & 7 & 10 & 10 & 10 & 10 \\
\hline Butachlor & 1,500 & 2 & 10 & 10 & 9.5 & 0 & 8 & 0 & 9 & 9 & 7 & 9 & 6 \\
\hline
\end{tabular}

Abbreviation of weed names is same as shown in Table 2.

Timing: Pre-emergence $=3$ DAT

Post-emergence $=12$ DAT

\section{Results}

\section{Herbicidal Activity and Crop Safety}

Wagner Pot Test and Concrete Pot Test

As shown in Tables 2 and 3 , herbicidal activity of DPX-F5384 was remarkably high. Annual broadleaf weeds were completely controlled by DPX-F5384 at $25 \mathrm{~g}$ a. i./ha. Also, at $50 \mathrm{~g}$ a. i. / ha good to excellent control of perennial weeds such as Scirpus juncoides, Sagittaria pygmaea, and Cyperus serotinus was obtained. Although weeds germinated and emerged in treated paddy soil, susceptible species ceased growing shortly thereafter. Stunted weeds exhibited mild chlorosis, reddening, and progressive necrosis as secondary symptoms. The herbicidal symptoms and processes of DPX-F5384 were similar to that of chlorsulfuron and metsulfuron. ${ }^{1,2)}$ Most weeds eventually died while certain relatively tolerant species remained green. However, these were also severely suppressed and kept noncompetitive except for Echinochloa oryzicola.

Rice plants were tolerant to DPX-F5384. Slight retardation of growth was caused by DPX-F5384 at $100 \mathrm{~g}$ a.i./ha, but plant activities recovered rapidly.

Field Test

Complete control of annual broadleaf weeds and excellent control of perennial weeds were obtained with DPX-F5384 at $50 \mathrm{~g}$ a. i./ha. However, even at $200 \mathrm{~g}$ a. i./ha control of Echinochloa oryzicola was not acceptable. Slight grow th retardation on rice was observed at $200 \mathrm{~g}$ a. i./ha, but its recovery was rapid (Table 4).

\section{Sensitivity Difference between Gramineous and Broadleaf Plants}

Remarkable differences in sensitivity to DPX-F5384 were seen between gramineous plants and broadleaf plants as shown in Table 5. Although phytotoxicity of DPX-F5384 even at $2 \mathrm{~g}$ a. i./ha was observed on Chinese 
Table 4. Herbicidal activity and crop injury of DPX-F5384

(Field Test)

\begin{tabular}{|c|c|c|c|c|c|c|c|c|c|c|c|c|c|}
\hline \multirow{2}{*}{ Chemicals } & \multirow{2}{*}{$\begin{array}{l}\text { Rate } \\
\text { g a.i./ha }\end{array}$} & \multirow{2}{*}{$\underset{\text { DAT }}{\text { Timing }}$} & \multicolumn{7}{|c|}{ Weed Control } & \multicolumn{4}{|c|}{ Crop Injury } \\
\hline & & & Eo & $\mathrm{Mv}$ & $\mathrm{Bl}$ & $\mathrm{Ea}$ & $\mathrm{Sj}$ & $\mathrm{Sp}$ & $\overline{\mathrm{Cs}}$ & V.C. & P. H.* & N.S.* & D. W. * \\
\hline \multirow[t]{3}{*}{ DPX-F5384 } & 50 & 5 & 3 & 10 & 10 & 10 & 9.5 & 9.5 & 9.5 & 0 & 102 & 29 & 105 \\
\hline & 100 & & 6 & 10 & 10 & 10 & 9.5 & 10 & 10 & 1 & 101 & 104 & 100 \\
\hline & 200 & & 9 & 10 & 10 & 10 & 10 & 10 & 10 & 2 & 100 & 102 & 96 \\
\hline Butachlor & 1,500 & & 9.5 & 7 & 9.5 & 10 & 9 & 0 & 5 & 1 & 97 & 98 & 99 \\
\hline
\end{tabular}

Timing: $0 \sim 0.5$ leaf stage of weeds, 3 leaf stage of rice

Eo: Eleocharis acicularia, Abbreviations same as shown in Table 2.

V. C. : Visual count ( $0 \sim 10$ rating scale),

P.H.* : Plant height ( $\%$ of untreated check)

N.S.* : No. of stems ( " )

D. W.*: Dry weight (

Weed control and crop safety tests were conducted in separate plots.

Table 5. Sensitivity of various crops to DPX-F5384

\begin{tabular}{|c|c|c|c|c|c|c|c|c|c|}
\hline \multirow{2}{*}{ Treatment } & \multirow{2}{*}{$\begin{array}{l}\text { Dose } \\
\text { g a. i./ha }\end{array}$} & \multicolumn{2}{|c|}{ Rice } & \multicolumn{2}{|c|}{ Wheat } & \multicolumn{2}{|c|}{ C. Cabbage } & \multicolumn{2}{|c|}{ Spinach } \\
\hline & & V.C. & F.W. & V.C. & F.W. & V.C. & $\overline{\text { F. W. }}$ & V.C. & F.W. \\
\hline \multirow{5}{*}{ DPX-F5384 } & 0 & 0 & $100 *$ & 0 & $100 * *$ & 0 & $100 * * *$ & 0 & $100 * * * *$ \\
\hline & 0.4 & 0 & 102 & 0 & 105 & 1 & 78 & 1 & 105 \\
\hline & 2 & 0 & 105 & 0 & 100 & 4 & 57 & 5 & 67 \\
\hline & 10 & 0 & 110 & 0 & 105 & 6 & 30 & 6 & 40 \\
\hline & 100 & 0 & 107 & 0 & 115 & 8 & 22 & 8 & 20 \\
\hline
\end{tabular}

V. C. : Visual Count $(0 \sim 10$ rating scale)

F. W. : Fresh Weight of Shoot ( $\%$ of untreated check)

$*: 0.07 \mathrm{~g} /$ plant, ** : $0.23 \mathrm{~g} /$ plant, *** $: 0.23 \mathrm{~g} /$ plant, $* * * *: 0.1 \mathrm{~g} / \mathrm{plant}$

Table 6 Mobility in paddy soil

\begin{tabular}{|c|c|c|c|c|c|c|}
\hline \multirow{2}{*}{ Compound } & \multirow{2}{*}{$\begin{array}{l}\text { Dose } \\
\text { g a. i./ha }\end{array}$} & \multirow{2}{*}{ Pan $t$} & \multicolumn{4}{|c|}{ Fresh Weight ( $\%$ of check) } \\
\hline & & & $\overline{0 \sim 1 \mathrm{~cm} *}$ & $1 \sim 2 \mathrm{~cm}^{*}$ & $2 \sim 3 \mathrm{~cm} *$ & $3 \sim 4 \mathrm{~cm} *$ \\
\hline \multirow[t]{4}{*}{ DPX-F5384 } & 75 & Ec & 78 & 78 & 100 & 104 \\
\hline & & $\mathrm{Sj}$ & 15 & 60 & 100 & 100 \\
\hline & 150 & $\mathrm{Ec}$ & 48 & 57 & 100 & 109 \\
\hline & & $\mathrm{Sj}$ & 10 & 48 & 96 & 100 \\
\hline \multirow[t]{2}{*}{ Butachlor } & 1,500 & $\mathrm{Ec}$ & 0 & 57 & 78 & 109 \\
\hline & & $\mathrm{Sj}$ & 0 & 52 & 95 & 110 \\
\hline
\end{tabular}

Ec : Echinochloa oryzicola, $\mathrm{Sj}$ : Scirpus juncoides

* Soil layer in cylinder

cabbage and spinach, there was no phytotoxicity at $100 \mathrm{~g}$ a. i./ha on the above-the-soil part of rice and wheat.

\section{Mobility in Paddy Water}

Relative mobility of DPX-F5384 in paddy soil was assessed by bioassay method as shown in Table 6. Severe and moderate growth inhibition on Scirpus juncoides was observed in the soil from the top and second ring, respectively. The result suggests DPX-F5384 is relatively immobile in the soil, which is similar to butachlor. Although it was not as 
apparent, a similar indication was seen on Echinochloa oryzicola.

\section{Discussion}

Data presented here indicate that DPXF5384 at a rate as low as $25 \mathrm{~g}$ a. i./ha provides excellent control of annual and perennial broadleaf weeds and sedges. At $50 \mathrm{~g}$ a. i./ha (pre- and post-emergence), the compound shows excellent control of Scirpus juncoides, Sagittaria pygmaea and Cyperus serotinus.

Rice plants were reasonably tolerant to DPX-F5384 up to $200 \mathrm{~g}$ a. i./ha rate under the tested conditions.

The mobility in paddy soil was minimal and similar to that of butachlor, which leached about $2 \mathrm{~cm}$ under the experimented conditions. These results also support the consistent activity of the compound.

As to the environmental safety, Ray has recently discovered that sulfonylurea herbicides inhibit cell division and plant morphogenesis by blocking the first step in the biosynthesis of the essential amino acids, valine and isoleucine in plants. ${ }^{3)}$ Our toxicological studies to date prove the very low toxicity of the compound.*

DPX-F5384 is promising as a new herbicide for paddy rice in terms of high biological activity, crop safeaty, low toxicity for mammals, wildlife and aquatic organisms. ${ }^{51}$

\section{Summary}

DPX-F5384, methyl 2-[C[C[( 4,6 -dimethoxypyrimidin-2-yl) amino] carbonyl] amino] sulfonyl] methyl benzoate was studied for biological activity, selectivity and mobility in paddy soil. At $25 \mathrm{~g}$ a. i./ha, the compound showed excellent control of annual broadleaf weeds and sedges in pot tests. Perennial weeds such as Eleocharis acicularis, Scirpus juncoides, Sagittaria pygmaea, and Cyperus serotinus were controlled at $50 \mathrm{~g}$ a. i./ha, however, control of Echinochloa oryzicola was not acceptable even at $200 \mathrm{~g}$ a. i./ha.

Rice plants were tolerant to DPX-F5384. Slight growth retardation was observed with the treatment at $200 \mathrm{~g}$ a. i./ha, but rice plants recovered rapidly.

The results of sensitivity in comparison with broadleaf crops indicated that rice is more highly tolerant to DPX-F5384 than Chinese cabbage or spinach.

Mobility of the compound in paddy soil was relatively limited $(2 \mathrm{~cm})$ and similar to that of butachlor.

\section{References}

1) Doig, R.I. and G. A. Carraro: DPX-T6376-A new broad spectrum cereal herbicide. Proc. Brit. Crop Prot. Conf. 1, 324 331 (1983).

2) RAY, T.B.: The mode of action of chlorsulfuron-A new herbicide for cereals. Pestic. Bio chem. Physiol. 17, 10 17 (1982).

3) RAy. T. B.: Site of action of chlorsulfuron -Inhibition of valine and isoleucine biosynthesis in plants. Plant Physiol. 75, 827 831 (1984).

4) Takeda S., T. Yuyama, R. C. Ackerson and R.C. WEIGEL: Selection of rice herbicide from several sulfonylurea compounds. Weed Res. Japan 30 (4) submitted (1985).

5) Yuyama, T., S. Takeda, H. Watanabe, T. Asami, S. Peudpaichit, J.L. Malassa and P. HeISS: DPX-F5384-A new broad spectrum rice herbicide. Proc. 9th APWSS Conf. (Supple.), 554 559 (1983).

(Received May 8, 1985)

*Du Pont Technical Bulletin E-46095 
新水稲用除草剂 DPX-F5384 の作用特性

武田俊司・湯山 猛 デュポン ジャパン

R. C. Ackerson $•$ R. F. Sauers $・$ L. W. Neal •

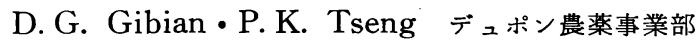

R. C. Weigel テネシー大学植物学部

\section{摘 要}

DPX-F5384 の除草活性, 作物安全性, 選択性および水田土壤中での移動性について検討した。除草活性と作物安 全性に関しては，温室内と戸外でのポット試験と固場試験によって検定した。また，イネ科作物と広葉作物との間の 感受性の差異については, 本剤の所定量を処理した畑土壌で, 水田土壌中での薬剤の移動性は, シリンダーを用いた 標準試験法により検定した。それらの結果は下記のように要約される。

1. 本剤 $25 \mathrm{~g}$ a. i. / ha の出芽前土壤処理と出芽後土壤兼茎葉処理は, 水田の 1 年生広葉雑草およびカヤツリグサ 科雑草に対し，ほぼ完全な防除効果を示した（Table 2)。

2. ホタルイ，マツバイ，ウリカワおよびミズガヤツリなどの多年生雑草に対しては，本剤 50gai/ha の出芽前土

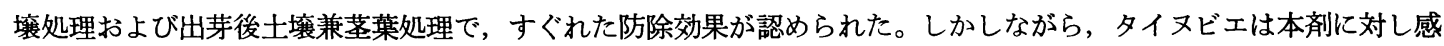
受性が低く，200gai/ha の薬量でも十分な防除効果を示さなかった（Table 2,3,4)。

3. 水稲に対する安全性については, 本剤 100 200gai/ha の出芽前, 後の土壤および土壤兼茎葉処理で, イネに 軽度の生育抑制が観察されたが，生育抑制は比較的短期間に回復した（Tables 3,4)。

4. イネ科作物と広葉作物の本剤に対する感受性には，大きな差異が認められた。イネ科作物（イネ，ムギ）は本 剤に高い耐性を示したが，広葉作物は顕著な感受性を示した（Table 5)。

5 ， 水田土壤中における本剤の移動性は比較的小さく，ブタクロールとほぼ同程度であった (Table 6)。 